\title{
Extrapancreatic and Pancreatic Actions of Glibenclamide in Rats*
}

\author{
W. Heptner, A. Zermatten, H.-M. Kellner, O. Christ, and J.-P. Felber \\ Hoechst AG, Frankfurt/Main, FRG, and Hôpital Cantonal Universitaire, Lausanne, Switzerland
}

\begin{abstract}
Summary. The aim of this study was to investigate the influence of glibenclamide on insulin release via insulinotropic gut factors and via a direct action on the pancreas. Maximum peripheral IRI levels appeared 1 minute after intragastric administration of the minimal effective dose of glibenclamide to rats. The corresponding drug levels were high $(600 \mathrm{ng} / \mathrm{g})$ in the duodenal mucosa, but low $(2 \mathrm{ng} / \mathrm{ml})$ in the peripheral serum. These concentrations were too low to cause insulin release by direct action on the pancreas. Intragastric glibenclamide increased the amount of "duodenal insulin releasing activity" (DIRA) in the mucosa immediately after drug administration. When glibenclamide was dissolved in plasma at a high concentration $(1 \mu \mathrm{g} / \mathrm{ml})$ and then injected into the coeliac trunk of an in-situ rat pancreas preparation, no additional effect on portal IRI levels was measured as compared with injection of serum alone. In contrast significant IRI release was noticed when glibenclamide was dissolved in serum $(1 \mu \mathrm{g} / \mathrm{ml})$ of rats pretreated with the drug intragastrically. The plasma of pretreated rats without addition of glibenclamide was ineffective. The results suggest that glibenclamide may have two effects, one releasing insulin at the pancreas directly, and the other inducing the release of a gastrointestinal factor which amplifies the first effect. Neither glibenclamide nor the factor alone can provoke an IRI release under physiological conditions. The possible importance of these findings for the regulation of insulin secretion is discussed.
\end{abstract}

Key words: Insulin release, glibenclamide, sulfonylureas, gastrointestinal hormones, modulation of insulin release, rat, intragastric administration, i. v. injection, extrapancreatic effect.

\footnotetext{
* Presented at the 11th EASD Congress, Munich, September 1975
}

It is generally accepted that the blood glucose lowering sulfonylureas promote their insulinotropic effects by acting directly on the pancreas. However, several points remain unexplained. There is a contradiction between drug pharmacokinetics and pharmacodynamics of glibenclamide $[1,16]$. After intragastric and i. v. administration of this drug the maximal concentrations of IRI were independent of the route of administration. The corresponding peripheral blood levels of the drug, however, were much lower after oral administration. Furthermore it has been found that the antidiabetic action of glibenclamide is still present after three times the $t_{50}$ of its elimination from the blood, when levels have become very low $(<40 \mathrm{ng} / \mathrm{ml})[25,1]$.

In 1969 a dual mode of action of glibenclamide was suggested [16], one via the release of gastrointestinal mediators, effective in releasing insulin, the other by direct induction of insulin release at the pancreas.

A study was carried out to investigate the effect of gastrointestinal mediators in the insulinotropic action of glibenclamide.

\section{Material and Methods}

Male SPF Wistar rats, weighing about $300 \mathrm{~g}$, were used, and unless otherwise stated were fasted overnight. When fed rats were used the animals had free access to Altromin ${ }^{\circledR}$. Glibenclamide was labelled with tritium in 1-position of the cyclohexyl ring by catalytic exchange, yielding a specific radioactivity of $1.9 \mathrm{Ci} / \mathrm{g}$. The material contained less than $1 \%$ radioactive contamination, and no exchange of label could be seen during short-term ( 2 hours) experiments in rats. The labelled glibenclamide was dissolved as sodium salt in saline at a concentration of $20 \mu \mathrm{g} / \mathrm{ml}$. 
$0.2 \mathrm{mg} / \mathrm{kg}$ of the solubilized drug was administered intragastrically by a stomach tube. This was the minimum effective dose in this species [2] Fasted animals were used for the kinetic studies in order to avoid variation of the results caused by different stomach content. The rats were sacrificed by decapitation at the times indicated in the figures. Heparinized plasma was prepared from the blood. The small intestine was removed in toto and rinsed with $20 \mathrm{ml}$ saline. Radioactivity was measured in the washing solution for glibenclamide determination. Samples of duodenal mucosa and liver were taken, homogenized in water and radioactivity was measured in an aliquot as described below.

The method used in another series of experiments is characterized by a system of donor and receptor rats [31] previously described. In brief: in the first subseries the donor rats were treated with the minimum effective dose of glibenclamide $(0.2 \mathrm{mg} / \mathrm{kg})$ intragastrically. In this experiment animals had free access to food to enhance insulin release in vivo. At the times indicated in figure 4 the animals were sacrificed by decapitation. Blood was collected for IRI determination in heparinized plasma. After laparatomy the duodenum was rapidly excised between the pylorus and the pancreaticobiliary duct. After rinsing the duodenum with $20 \mathrm{ml}$ saline $\left(4{ }^{\circ} \mathrm{C}\right)$, the mucosa was scraped off, weighed and homogenized in cold saline $(100 \mathrm{mg} / \mathrm{ml})$, with a Potter homogeniser. The time between sacrifice and homogenisation was constant at 2 minutes. After centrifugation $(3500 \mathrm{~g}, 30 \mathrm{~min})$ the supernatant was collected and stored at $-20^{\circ} \mathrm{C}$ until used for determination of DIRA in the receptor rat.

The receptor rats were fasted 24 hours and anaesthetised with intraperitoneal pentobarbital $(25 \mathrm{mg} / \mathrm{kg}$ body weight). After laparatomy the coeliac trunk was prepared for injection of the extracts and a catheter was inserted into the portal vein. Ten min later $0.7 \mathrm{ml}$ of blood was collected for basal measurements. $0.2 \mathrm{ml}$ of the extracts was injected into the coeliac trunk within about $10 \mathrm{sec}$ onds. $1 \mathrm{~min}, 5 \mathrm{~min}, 10 \mathrm{~min}$, and $15 \mathrm{~min}$ after extract injection, $0.7 \mathrm{ml}$ portal blood was taken for IRI determination. In addition to the results of figure 4, controls containing $0.5 \mu \mathrm{g}$ glibenclamide per $\mathrm{ml}$ extract of duodenal mucosa were tested. The experimental modifications of the other subseries are schematically described in figure 5 .

IRI was determined in the portal blood of receptor rats by a double antibody radioimmunoassay [14] using rat insulin standard (Novo, batch no $\mathbf{R}$ 171). Radioactivity measurements of ${ }^{3} \mathrm{H}$-glibenclamide were performed by liquid scintillation counting after combustion of fluids and homogenates of tissues in an automatic sample oxidizer.
Results were presented as mean \pm SEM. For statistical comparison the t-test for paired differences was used.

\section{Results}

Maximal IRI levels in peripheral blood occurred one minute after both intragastric and i. v. administration, while the glibenclamide blood levels differed by a factor of 1000 , depending on the route of administration (Fig. 1).

When measured at 1, 3, 5 and 10 min after intragastric administration the lumen of the small intestine repeatedly contained $60 \%$ of the administered glibenclamide (Fig. 2). The duodenal mucosa already contained maximal glibenclamide concentrations (600 ng/g) after $1 \mathrm{~min}$ (Fig. 3). This level remained constant when measured after $1,3,5$ and $10 \mathrm{~min}$, respectively. Calculated from the concentration in the liver, the total drug absorption at the same time was estimated to be less than $0.5 \%$ of the minimal effective dose administered.

When $0.2 \mathrm{mg} / \mathrm{kg}$ glibenclamide was administered to fed rats intragastrically an immediate increase of DIRA was observed (Fig. 4). The maximal concentration appeared in the mucosal material taken 30 seconds after intragastric administration.

The peak of insulin releasing activity (DIRA) preceded the rise in plasma IRI. The concentration of glibenclamide in mucosal extracts was always less than $0.2 \mu \mathrm{g} / \mathrm{ml}$. When $0.5 \mu \mathrm{g} / \mathrm{ml}$ glibenclamide were added to extracts and injected into the coeliac trunk of the receptor rat, no additional effect was observed [32].

Results of the study to characterize a possible direct insulinotropic effect of glibenclamide are shown in Figure 5. Only in experiment $\mathrm{E}$ (fed donor rats, pretreated with glibenclamide, and glibenclamide added to donor rat plasma) could an increase in portal insulin of receptor rats be observed. Maximal IRI concentrations appreared $1 \mathrm{~min}$ after administration. Later the concentration fell, but remained significantly above that found in all other experiments.

\section{Discussion}

The pharmacokinetics and metabolism of glibenclamide in various animal species and man have been reported in previous papers $[6,16,19,27]$. The kinetics of glibenclamide and serum IRI have been compared in dogs using $i$. v. injection and intragastric administration [16]. The results suggested that gastrointestinal mediators may be involved in the insulin releasing action of this drug. The more 


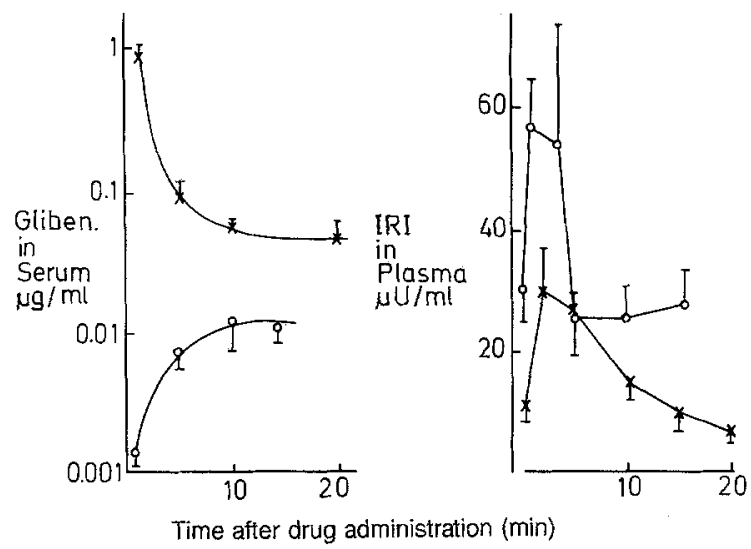

Fig. 1. Glibenclamide ${ }^{3} \mathrm{H}$ and peripheral IRI after intravenous $(X \ldots X$, blood from orbital vein) and intragastral $(0-0$, blood collected after decapitation) administration of $0.2 \mathrm{mg} / \mathrm{kg}$ (sodium salt solution) to fasted rats. Mean \pm SEM, $\mathrm{n}=5$

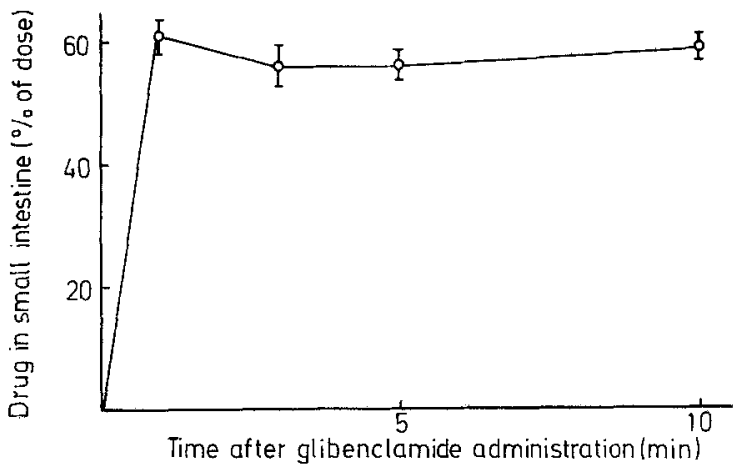

Fig. 2. Glibenclamide- ${ }^{3} \mathrm{H}$ in lumen of small intestine of fasted rats after intragastric administration of $0.2 \mathrm{mg} / \mathrm{kg} . \mathrm{M} \pm \mathrm{SEM}, \mathrm{n}=5$

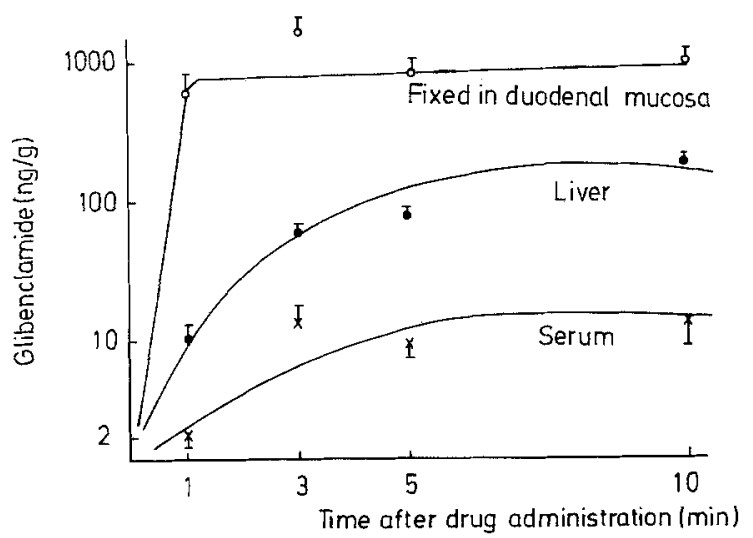

Fig. 3. Glibenclamide- ${ }^{3} \mathbf{H}$ in plasma, liver and duodenal mucosa of fasted rats after administration of $0.2 \mathrm{mg} / \mathrm{kg}$ intragastrically. $\mathrm{M}$ $\pm \mathrm{SEM}$, presented in a semi-logarithmic scale, $\mathbf{n}=5$

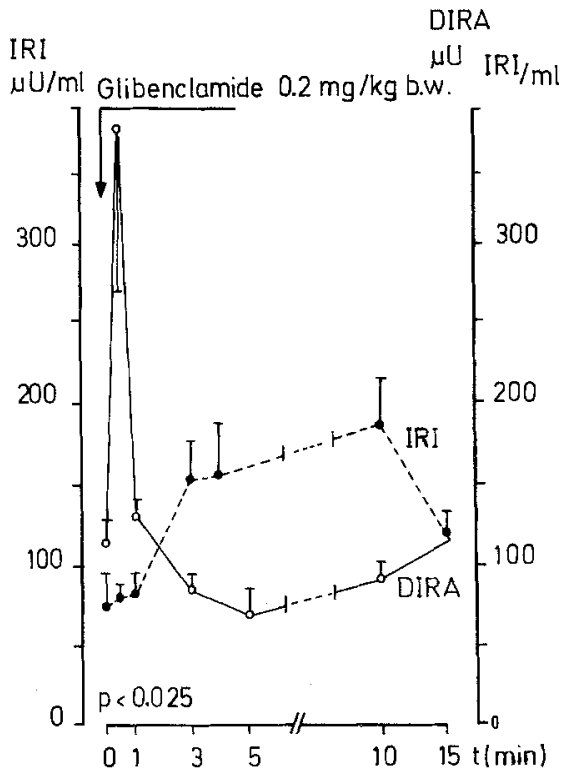

Fig. 4. IRI in peripheral blood and duodenal insulin releasing activity (DIRA) in fed (donor) rats after administration of $0.2 \mathrm{mg} / \mathrm{kg}$ glibenclamide. $\mathrm{M} \pm \mathrm{SEM}, \mathrm{n}=5$. - DIRA is expressed as IRI $(\mu \mathrm{U} / \mathrm{ml})$ in the plasma of portal blood which was collected $1 \mathrm{~min}$ after injection of donor rat mucosal extract into the coeliac trunk of receptor rats. The statistics of DIRA values were done by comparison of the different data with the value at time zero

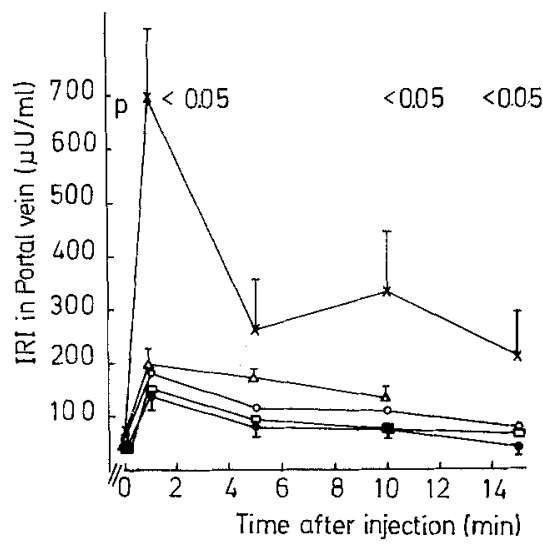

Fig. 5. Effect of glibenclamide on IRI output from an in situ rat pancreas preparation. $0.2 \mathrm{ml}$ of the following solutions were injected into the coeliac trunk of the receptor rats.

O_- E Experiment A: Plasma of fasted rats.

$\longrightarrow$ Experiment B: As Exp. A, addition of $1 \mu \mathrm{g} / \mathrm{ml}$ glibenclamide

$\triangle-\triangle$ Experiment $\mathrm{C}$ : Plasma of fed rats, pretreated with $0.2 \mathrm{mg} / \mathrm{kg}$ glibenclamide

$\square-\square$ Experiment D: Plasma of fed rats, addition of $1 \mu \mathrm{g} / \mathrm{ml}$ glibenclamide

$x \_\times$Experiment E: As Exp. C, addition of $1 \mu \mathrm{g} / \mathrm{ml}$ glibenclamide.

Blood of pretreated donor rats was collected $10 \mathrm{~min}$ after intragastric glibenclamide administration 
detailed data reported here support these previous findings. After intragastric administration a rapid accumulation of glibenclamide and an increase of DIRA in the mucosa correlate well with the rise in serum IRI. After about 20 min metabolites reach the intestinal tract via the bile. Therefore the pharmacokinetics of the drug cannot be calculated from tracer studies without making a correction for the metabolites.

A relatively high concentration of glibenclamide dissolved in plasma of fasted rats and injected into the coeliac trunk had no more effect on IRI levels than the plasma alone. This indicates that the plasma glibenclamide concentration used in this experiment has no direct effect on insulin release from the pancreas of the receptor rat. However, when the drug was added to plasma of rats pretreated with glibenclamide intragastrically, there was a significant elevation of IRI in the portal vein. In the plasma of pretreated rats a factor seems to be present which allows glibenclamide to have a direct effect on the pancreas.

The absence of an effect of glibenclamide dissolved in plasma of fasted or fed rats contradicts the well established direct action shown repeatedly by in vitro experiments $[3,12,21,22,30]$. Mariani [22] found that $1 \mathrm{ng}$ glibenclamide/ml albumin containing medium is sufficient to release insulin from the perfused pancreas. Other authors, however, have reported much higher minimal effective drug concentrations: $250 \mathrm{ng} / \mathrm{ml}$ [30], $600 \mathrm{ng} / \mathrm{ml}$ [21], $2500 \mathrm{ng} / \mathrm{ml}$ [12], and $8000 \mathrm{ng} / \mathrm{ml} \mathrm{[3].} \mathrm{According} \mathrm{to}$ these findings it seems likely that the concentrations used in the experiments reported here are too low to cause a direct effect of glibenclamide, except when compared with the data of Mariani [22].

Furthermore it should be considered that the uptake of glibenclamide into the islets is decreased by protein binding (serum albumin) [15]. The protein binding of glibenclamide in rat serum exceeds $99 \%$ [13]. In our laboratory it was found that the binding of glibenclamide by serum albumins is less than $90 \%$, with variation between different products and batches. Therefore the in vitro effect of the drug on IRI release from cultures of pancreatic cells could be observed in a protein free medium and in the presence of albumin, but not in the presence of complete serum [17].

About 50 years ago Staub [28] and Traugott [29] observed that oral glucose increases the utilisation rate of a second oral glucose load. This has since been confirmed by Dupré [8], Conard [7], and Perley [23]. Recently Cerasi $[4,5]$ has found that in man intravenous glucose exerts two different effects, one which initiates the release of insulin and a second one which modulates the first action. The results reported here suggest to combine the assumption of a dual effect of glucose on insulin secretion with the findings of insulin release caused by a variety of gut factors. This combination may be interpreted as follows: after food and/or drugs such as glibenclamide by mouth, high concentrations of glucose, amino acids and drug appear in the gut. After intravenous administration of these components, the mucosal concentration may be also elevated via the circulation. The increasing concentrations of these substrates in the mucosal cells could cause the liberation of gut factor(s) which in their turn induce insulin release in the pancreas $[10,11,31,32,33]$. In the pancreas the gut factor(s) may amplify the direct insulinotropic action of the substrates. Under these experimental conditions neither the gut factor(s) nor glibenclamide alone could release insulin from the pancreas. This concept may explain the following observations on the kinetic pattern of IRI release in man: glucose [9, 20, 23], amino acids [24] and sulfonylureas [16] are more effective in insulin release when given intragastrically or intraduodenally than intravenously. Within 2-5 min of intraduodenal glucose $[26,18]$ to man a high IRI output could be found in the portal blood, at a time when the portal blood glucose level was not increased. It is assumed that the gut factor may be released before the glucose has passed the intestinal wall. The IRI release after oral glucose in man [26] and after glibenclamide in dogs [16] follows a biphasic pattern. The first peak, seen very early, may be explained by the amplifying action of the gut factor in presence of a basal intracellular glucose concentration. The later peak may be caused by the gut factor together with increasing concentrations of substrates now being absorbed from the intestine. It has been shown repeatedly that a second glucose load regularly causes a higher IRI peak than the first one $[4,8]$. This can be explained if one assumes that gut factor(s) released by the second load are superimposed on that of the first one, i. e. the amplifier is thought to have a relatively long half-life.

In an another paper we suggest that a similar mechanism may regulate the insulin release in man [32].

In further studies we intend to investigate whether DIRA corresponds to one of the characterized intestinal gut factors and whether other sulfonylureas act in the same manner.

Acknowledgement. We thank Dr. Schlichtkrull (NOVO, Copenhagen) for the gift of rat insulin. 


\section{References}

1. Balant, L., Zahnd, G. R., Weber, F., Fabre, J.: Behaviour of glibenclamide on repeat administration to diabetic patients. Eur. J. Clin. Pharmacol. 11, 19-25 (1977)

2. Bänder, A., Pfaff, W., Schmidt, F.H., Storck, H., Schröder, H. G.: Zur Pharmakologie von HB 419, einem neuen, stark wirksamen oralen Antidiabeticum. Arzneim. Forsch. (Drug Res.) 19, 1363-1368 (1969)

3. Burr, M., Stauffacher, W., Balant, L., Renold, A. E., Grodsky, G. M.: Regulation of insulin release in perifused pancreatic tissue. Acta Diabetol. Lat. 6, Suppl. 1, 580-596 (1969)

4. Cerasi, E.: Potentiation of insulin release by glucose in man. Acta Endocrinol. (KbH.) 79, 483-501 (1975)

5. Cerasi, E.: Potentiation of insulin release by glucose in man. Acta Endocrinol. (Kbh.) 79, 502-510 (1975)

6. Christ, O. E., Heptner, W., Rupp, W.: Investigations on absorption, excretion and metabolism in man after administration of ${ }^{14} \mathrm{C}$-labelled HB 419 . Horm. Metab. Res. Suppl., 1, 51-54 (1969)

7. Conard, V.: Mesure de l'assimilation du glucose; bases théoriques et applications cliniques. Acta Gastroenterol. Belg. 18, 655-705 (1955)

8. Dupré, J.: An intestinal hormone affecting glucose disposal in man. Lancet 1964 II, 672-673

9. Elrick, H., Stimmler, L., Hlad, C. J., Arai, Y.: Plasma insulin response to oral and intravenous glucose administration. J. Clin. Endocrinol. Metab. 24, 1076-1082 (1964)

10. Fasel, J., Hadjikhani, H., Felber, J.P.: The insulin secretory effect of the human duodenal mucosa. Gastroenterology $\mathbf{5 9}$, 109-113 (1970)

11. Felber, J.P., Zermatten, A., Dick, J.: Modulation, by food, of hormonal system regulating rat pancreatic secretion. Lancet 1974 II, 185-187

12. Grodsky, M., Curry, D., Landahl, H., Bennett, L.: Further studies on the dynamic aspects of insulin release in vitro with evidence for a two-compartmental storage system. Acta Diabetol. Lat. 6, Suppl. 1, 554-579 (1969)

13. Hajdú, P., Kohler, K.F., Schmidt, F.H., Spingler, H.: Physikalisch-chemische und analytische Untersuchungen an HB 419. Arzneim. Forsch. (Drug Res.) 19, 1381-1386 (1969)

14. Hales, C.N., Randle, P. J.: Immunoassay of insulin with insulin antibodies precipitate. Biochem. J. 88, 137-146 (1963)

15. Hellmann, B., Schlin, J., Täljedal, I. B.: The pancreatic $\beta$-cell recognition of insulin secretagogues, IV. Islet uptake of sulfonylureas. Diabetologia 9, 210-216 (1973)

16. Heptner, W., Christ, O., Kellner, H.-M., Rupp, W.: Pharmacokinetics of a new highly effective hypoglycemic sulfonylurea derivative. Acta Diabetol. Lat. 6, Suppl. 1, 104-115 (1969)

17. Heptner, W., Kellner, H.-M., Hilwig, I., Christ, O., Zermatten, A., Felber, J.-P.: Studies on the participation of duodenal insulin releasing activity in the $\beta$-cytotropic action of glibenclamide. Diabetologia 11, 349-350 (1975)

18. Karamanos, B., Butterfield, W.J.H., Asmal, A.C., Cox, B.D., Whichelow, M.J.: The pattern of early insulin response to oral glucose. Postgrad. Med. J. 47, (Suppl.) 440-443 (1971)

19. Kellner, H.-M., Christ, O., Rupp, W., Heptner, W.: Resorption, Verteilung und Ausscheidung nach Gabe von ${ }^{14} \mathrm{C}$-markiertem HB 419 an Kaninchen, Ratten und Hunde. Arzneim. Forsch. (Drug Res.) 19, 1388-1400 (1969)
20. McIntyre, N., Holdsworth, C. D., Turner, D. S.: Intestinal factors in the control of insulin secretion. J. Clin. Endocrinol. Metab. 25, 1317-1324 (1965)

21. Löffler, G., Trautschold, I., Schweitzer, T., Lohmann, E.: Zur Wirkung von HB 419 und Tolbutamid an isolierten Langerhans'schen Inseln der Ratte. Arzneim. Forsch. (Drug Res.) 19, 1469-1472 (1969)

22. Mariani, M.-M.: The action of sulfonylureas on the insulin secretion of the perfused rat pancreas. Acta Diabetol. Lat. 6, Suppl. 1, 256-270 (1969)

23. Perley, M. J., Kipnis, D. M.: Plasma insulin response to oral and intravenous glucose: Studies in normal and diabetic subjects. J. Clin. Invest. 46, 1954-1962 (1967)

24. Raptis, S., Dollinger, H.C., Schröder, K.E., Schleyer, M., Rothenbuchner, G., Pfeiffer, E.F.: Differences in insulin, growth hormone and pancreatic enzyme secretion after intravenous and intraduodenal administration of mixed amino acids in man. N. Engl. J. Med. 288, 1199-1202 (1973)

25. Raptis, S., Pfeiffer, E. F.: Progress in oral therapy of diabetes mellitus with sulfonylureas of the second generation. Acta Diabetol. Lat. 9, 865-899 (1972)

26. Reyes-Leal, B., Castro, A., Bernal, E., Guardiola, O.: Le role du duodénum dans l'insulino-sécrétion. Sem. Hop. Paris 49, 1611-1617 (1973)

27. Rupp, W., Christ, O., Heptner, W.: Resorption, Ausscheidung und Metabolismus nach intravenöser und oraler Gabe von HB $419-{ }^{14} \mathrm{C}$ an Menschen. Arzneim. Forsch. (Drug Res.) 19, 1428-1434 (1969)

28. Staub, H.: Untersuchungen über den Zuckerstoffwechsel des Menschen. I, Mitteilung: Über das Verhalten des Blutzuckers nach peroraler Zufuhr kleiner Glucosemengen. Z. Klin. Med. 91, 44-60 (1921)

29. Traugott, K.: Über das Verhalten des Blutzuckerspiegels bei wiederholter und verschiedener Art enteraler Zuckerzufuhr und dessen Bedeutung für die Leberfunktion. Klin. Wochenschr. 1, 892-894 (1922)

30. Weinges, K.F., Biro, G., Kettl, H., Mitzuno, M.: Vergleichende Untersuchungen zwischen HB 419 (Glibenclamid) und Tolbutamid über ihre Wirkung auf die Insulingabe an isolierten Inseln des Rattenpankreas in vitro. Arzneim. Forsch. (Drug Res.) 19, 1467-1469 (1969)

31. Zermatten, A., Felber, J.-P.: Sensitivity to glucose of an intestinal factor stimulating insulin release. Horm. Metab. Res. 6, 272-274 (1974)

32. Zermatten, A., Heptner, W., Delaloye, B., Séchaud, R., Felber, J.-P.: Extrapancreatic effect of glibenclamide: Stimulation of duodenal insulin releasing activity (DIRA) in man. Diabetologia 13, 85-88 (1977)

33. Zermatten, A., Felber, J.-P.: Stimulation or inhibition of insulin release by duodenal mucosa extracts removed after carbohydrates, amino acids or fat intake. Acta Endocrinol. (Kbh.) (Suppl.) 199, Abst. No. 48 (1975)

Received: March 4, 1976, and in revised form: March 25, 1977

Dr. W. Heptner

Mediznische Abteilung

Hoechst AG, H 840

Postfach 800320

D-6230 Frankfurt/M 80

Federal Republic of Germany 